\title{
Changes in the Intensity and Hardships of Hospital Work in France (1998-2013)
}

\section{Samia Benallah and Jean-Paul Domin}

Translator. Nicholas Sowels

\section{CpenEdition \\ Journals}

\section{Electronic version}

URL: http://journals.openedition.org/travailemploi/10006

DOI: 10.4000/travailemploi.10006

ISSN: 1775-416X

\section{Publisher}

DARES - Ministère du Travail

\section{Printed version}

Date of publication: 1 March 2020

Number of pages: 5-30

ISSN: 0224-4365

\section{Electronic reference}

Samia Benallah and Jean-Paul Domin, "Changes in the Intensity and Hardships of Hospital Work in France (1998-2013)", Travail et Emploi [Online], Hors-série | 2020, Online since 01 March 2021,

connection on 30 April 2021. URL: http://journals.openedition.org/travailemploi/10006 ; DOI: https:// doi.org/10.4000/travailemploi.10006 


\title{
Changes in the Intensity and Hardships of Hospital Work in France (1998-2013)
}

\author{
Samia Benallah, ${ }^{* *}$ Jean-Paul Domin ${ }^{* * *}$
}

\begin{abstract}
This paper looks at the evolution of working conditions in France's hospital sector over the fifteen years to 2013. The issue is important in view of the extensive reforms undertaken in the sector since the early 1990s, which have led to profound reorganizations. We start by reviewing the state of knowledge and data of working conditions in hospitals. In the light of the last three editions of France's Working Conditions survey (enquête Conditions de travail), we then look at the changes in the pace of work and in the different forms of hardship at work that occurred in French hospitals between 1998 and 2013. We then compare these with observations for other sectors. Finally, we analyze, ceteris paribus, the current specificities of the hospital sector in terms of exposure to work pace, staggered schedules, physical hardships and a worsening working environment. We observe that there was an acceleration in work pace faced by hospital staff in the period studied. This was accompanied by a slight alleviation of physical hardships. However, working conditions in hospitals remain particularly stressful.
\end{abstract}

$\mathrm{F}_{\mathrm{b}}$ rance's public hospital sector has been subject to numerous reforms since the beginning of the 1990s, aimed at reducing costs. These reforms have concerned both the financing and governance of hospitals, and in particular the exercise of public tutelage. ${ }^{1}$ The main reform in financing took place in 2003, with the implementation of activity-based pricing (tarification à l'activité or T2A). This new pricing method aimed to simulate market mechanisms by assigning an average price to medical procedures. In doing so, it was supposed to encourage hospitals to provide care at lower costs by introducing yardstick competition between establishments.

\footnotetext{
* Traduction: Nicholas Sowels. Article published in French in Travail et Emploi, no 152, 2017.

** Laboratoire Regards, université de Reims Champagne-Ardenne; samia.benallah@univ-reims.fr.

*** Laboratoire Regards, université de Reims Champagne-Ardenne, Centre d'économie de l'université Paris 13 (CEPN); jp.domin@univ-reims.fr.

1. The creation of Regional Hospitalization Agencies (Agences régionales de l'hospitalisation) in 1996 especially, and that of Regional Health Agencies (Agences régionales de la santé) in 2009.
} 
Based on various foreign experiences, the economic literature has highlighted the risks associated with this type of payment, including: patient selection (SILVERMAN, SKINNER, 2004), as hospitals have an interest in keeping low-cost patients and avoiding expensive patients; declines in the quality of care due to premature discharging of patients as prices are disconnected from the length of hospitalizations (NEWHOUSE, 2003); and the refocusing of hospitals' work on lucrative specialties and cuts in unprofitable care (SCANLON, 2006).

From the point of view of internal organization, this new method of financing has led to a strong rationalization of activity within hospitals, as part of a constant search for productivity gains. It has been accompanied by the implementation of management techniques directly inspired by the private sector (DOMIN, 2015). Organizational and managerial techniques resulting from new public management have thus been applied to hospitals (PIERRU, 2007). These manifest themselves in the rationalization of patient flows, the standardization of care procedures, and also implementation of new work assessment methods such as timing tasks. Staff are thus encouraged to improve their productivity through new performance indicators.

These profound changes in hospitals and their functioning have impacted working conditions in the sector. Empirical analyzes carried out from the mid-2000s - mainly using qualitative field surveys - indicate an "increasing pressure from work pace constraints" (GHEORGHIU, MOATTY, 2013, p. 250). This has been accompanied by a deterioration of working conditions in the hospital sector (BELORGEY, 2010). These trends, however, are not specific to hospitals, and have been observed for all sectors during the same period. Élisabeth ALGAVA and her co-authors (2014) have thus highlighted a resumption of work intensification for all workers between 2005 and 2013, following a period of stabilisation between 1998 and 2005 (BUÉ et al., 2007). Physical constraints and pressures at work have also increased.

In the hospital sector, the search for greater productivity to improve its performance, and thereby reduce costs, faces another challenge the public authorities must tackle at the same time, namely the risk of staff shortages, and in particular of nursing staff, in a context of France's aging population. This affects hospital staff too (Noguera, LARTigau, 2009). The lack of job attractiveness, resignations and early retirements, as well as high staff turnover and absenteeism for health reasons all threaten lasting personnel shortages and cause major disorganizations within the sector (ESTRYN-BÉHAR, 2008). Improving working conditions is one lever available to the public authorities to limit these threats, and it is clearly central in a sector in which work is particularly physically and mentally demanding, causing premature professional exhaustion. Since the 2010s, the public authorities have taken initiatives to this end, especially through social dialogue or quality of work life improvements. ${ }^{2}$ We may assume that these initiatives have had a beneficial impact on hospital staff's working conditions.

2. On these issues see Couty (2013), in particular. 
Given these seemingly contradictory forces, which are liable to affect working conditions, work in the hospital sector has been undergoing major changes, raising many questions. In this context of profound reforms and permanent reorganization, how have working conditions in hospitals evolved over the past fifteen years? Has there been an intensification of work, as in other sectors? Is this more marked in hospitals? Has it been accompanied by a softening of "historical" working constraints, or indeed a hardening?

In this article, we propose to answer these questions by analyzing the evolution of work intensity and hardships in the hospital sector, since the end of the 1990s, compared to other sectors of activity. We do not take an evaluative approach, which would consist in attributing observed changes in working conditions to the reforms implemented. Instead, we adopt a comparative approach whose aim is to point out differences in development between hospitals and other sectors. Our work thus completes the panorama of working conditions in healthcare establishments drawn up by Julien LOQUET and Layla RICROCH (2014).

To do this, we use individual data from the last three editions of France's Working Conditions survey (enquête Conditions de travail), covering the period from 1998 to 2013. These data have the twofold advantage of describing working conditions in detail, as they are experienced by employees, while also using a large sample which allows differentiated analyzes to be carried out according to the sector of activity. We set out our work here in three stages. After presenting the state of knowledge concerning working conditions in hospitals, especially changes in recent years, we describe the data and the methodology used. Lastly, we will detail and discuss the main results obtained.

\section{The Demands of Hospital Work: the State of Knowledge}

The organization of work in hospitals has to meet certain requirements of equal access and continuity of care, which constrain the sector especially in terms of working conditions. These are physically demanding, and employees are over-exposed to certain potentially-pathogenic constraints. Competition between hospitals via T2A and the introduction of managerial techniques directly inspired by the private sector may also have accelerated the pace of work.

\section{Demanding Working Conditions}

The working conditions and constraints faced by French hospital staff have been the subject of increased attention by researchers and public authorities since the beginning of the 2000s especially. These questions relate to a triple public health challenge (LAMY et al., 2013). First, there is the issue of how the work of hospital staff can be maintained given demographic aging, which affects staff in the sector itself 
(KRANKLADER et al., 2013). Then, there is the question of preserving staff health in the face of permanent changes and the profoundly-reformed context. Lastly, the quality of care needs to be maintained in an increasingly financially-constrained working environment.

This increased attention given to hospital working conditions has been accompanied by a significant development of databases allowing them to be analyzed in more detail, and more generally the organization of work in the sector. Analyses include: i) France's research programme on Promoting the Health and Satisfaction of Caregivers at Work in Europe (PRESST, Promouvoir en Europe santé et satisfaction des soignants au travail) as part of the European Nurses Early Exit Study (NEXT), from 2002 onwards; ii) the Conditions and Organization of Work of Employees in Health Establishments survey (COTAES, Conditions et organisation du travail des actifs en établissements de santé) in 2003; iii) the extension of the survey on Organizational Changes and Computerization (COI-H, Changements organisationnels et informatisation) of staff in public and private health establishments in 2006; and iv) the over-representation of hospital workers in the 2013 edition of the Working Conditions survey. In addition to these quantitative data, there have been field surveys aimed at deepening certain aspects of work reorganizations underway within the hospital sector. ${ }^{3}$

These sources have made it possible to improve knowledge appreciably about work constraints existing in hospitals. We are not seeking here to present them exhaustively, but to target working conditions which have deleterious effects on health and life expectancy. We are thus interested in a "set of noxious and potentially pathogenic constraints present throughout employees' professional lives" (MolinIÉ, VOLKOFF, 2006, p. 96). According to epidemiological studies, such constraints exist in three types: staggered hours and shift work, tasks requiring significant physical effort, and exposure to a toxic work environment (LASFARGUES, 2005).

Staggered hours and shift work are especially widespread in hospitals, insofar as they are essential to equal access to care and continuity of care. Night or weekend work, on-call duty and on-call duty outside normal working hours are one of the specific features of hospital services. Thus, according to the COI-H survey, nearly half of staff in public and private health establishments frequently work Saturdays or Sundays, and nearly one in four employees frequently work at night (CORDIER, 2009). These constraints concern more especially medical staff, nurses and nursing assistants, and are more frequent in France's public hospital services. Shift work is also over-represented in the public hospital sector: according to the Medical Surveillance Survey of Employee Exposure to Occupational Risks (SUMER, Surveillance médicale des expositions des salariés aux risques professionnels) ${ }^{4}$ in 2010 , nearly $44 \%$ of workers in this sector have some shift work, compared to $16 \%$ in all sectors (ARNAUDO et al., 2013).

3. On this issue, readers may turn to Raveyre, UGHetto, 2003; ACKer, 2005; GHeOrghiu, MoAtTy, 2005; and Divay, GADÉA, 2008, among others.

4. This was a survey coordinated by the Directorate for the Animation of Research, Studies and Statistics (Direction de l'animation de la recherche, des études et des statistiques, DARES) and the Directorate General of Labour (Direction 
Significant physical exertion is also common in hospitals. Using data from the 2003 Hospital Working Conditions and Organization (Conditions et organisation du travail à l'hôpital) survey, Romuald LE LAN and Dominique BAUBEAU (2004) have shown that workers are particularly exposed to four physical hardships, including: prolonged standing, carrying heavy loads, carrying out painful and tiring movements, as well as frequent and long movements by foot. They also show that exposure to the last two constraints increased significantly between 1998 and 2003. Here again, there are significant differences between professions, with nursing assistants being the most exposed (93\% of them were affected by having to move heavy loads in the public hospital sector, in 2003). However, exposure to intense physical exertion seems to have been reduced in hospitals more recently, even if it remains clearly over-represented in this sector (LOQUET, RICROCH, 2014).

Finally, the overall working environment also appears to be much less favorable in hospitals. Data from the 2010 SUMER survey reveal a pronounced overexposure of hospital employees to chemical and biological risks (ARNAUDO et al., 2013). Three quarters of them are exposed to biological risks, mainly through contact with patients. More than half are also exposed to at least one chemical product, compared to one third of all workers, in all sectors combined. Hospital staff are also over-represented with regard to the simultaneous exposure to at least three chemical agents: this affects one in four public hospital workers, in contrast to $14 \%$ for all employees.

\section{Did the Pace of Work in Hospitals Increase?}

The notion of work intensity is difficult to grasp. As Thomas Amossé and Michel GollaC (2008) have emphasised, it actually covers various meanings depending on the type of organization concerned. Work intensity may refer to the number of operations per unit of time in Tayloristic organizations. But it may also, for example, refer to the relationship between means and objectives in more modern forms of organization characterized by strong worker autonomy. Comparing work intensity between sectors of activity therefore seems difficult. Without claiming to offer a complete and definitive definition of work intensity, statistical surveys on working conditions have nevertheless made it possible to understand better its evolution since the beginning of the 1980s. Here, work intensity is identified through the various constraints weighing on the pace of work (the speed of machines or automatic movement of products, standards or deadlines to be respected, external requests from the public, etc.). These in turn are underpinned by different organizational logics (VALEYRE, 2001). The questions relating to such work pace constraints, present in the various editions of the Working Conditions survey, have made it possible to highlight an intensification of work in France, from the mid-1980s onwards, across all sectors (Algava et al., 2014).

générale du travail, DGT), and it was carried out by occupational physicians. Its aim was to measure in detail occupational risks that employees face at work. The survey was conducted three times: in 1994-1995, in 2002-2003 and in 2009-2010. 
The hospital sector has not been spared such intensification. By comparing the results of the Working Conditions survey in 1998 with those of the Hospital Working Conditions and Organization survey in 2003, R. LE LAN and D. BAUBEAU (2004) thus observed that the share of hospital workers who declare that their pace of work is imposed by production standards or deadlines to be met within one hour at most, had doubled over the period, from $24 \%$ to $48 \%$. This increase is all the more spectacular as it is out of all proportion compared to increases observed over the same period for all workers: the share of persons subject to a work pace imposed by production standards or deadlines to be observed within one hour at most, rose from $23 \%$ to $25 \%$ between 1998 and 2005, according to data collected in the two editions of the corresponding Working Conditions survey (BUÉ et al., 2007). The results obtained by R. LE LAN and D. BAUBEAU (2004) are however derived from the comparison of two distinct data sources, and the authors suggest they should be considered with caution.

The same precaution is called for with more recent results, which show a significant easing of pace constraints within the hospital sector, between 2003 and 2013 (LOQUET, RICROCH, 2014). Having a work rate imposed by the automatic movement of a product, or the speed of a machine affected nearly $22.5 \%$ of staff in the sector in 2003, compared with $6.8 \%$ and $7.5 \%$ of staff respectively in 2006 and 2013. A work rate imposed by production standards or deadlines to be met within one hour affected $30 \%$ of hospital workers in 2013, compared to $48 \%$ in 2003 . Finally, the share of staff declaring they face a work pace set by other technical constraints appears to have more than halved between 2003 and 2013, falling from 39\% to 18\%. These encouraging results are interpreted by the authors of the study as "an overall reduction in the pressure from work pace" (p. 2), even if these findings are based on the use of three different data sources, whose comparability is not guaranteed: the Conditions and Organization of Work of Employees in Health Establishments survey (COTAES) of 2003, the Organizational Changes and Computerization survey in the hospital sector (COI-H) of 2006 and the Working Conditions survey of 2013. These results are moreover all the more surprising as between 2003 and 2006, 46\% of employees of health establishments questioned within the framework of the COI-H survey also declared feeling a sharpening of work pace constraints (CORDIER, 2009).

The question of changes in work pace constraints within the hospital sector thus remains to be clarified, especially more recently. Yet the fact remains that certain constraints are particularly significant in this sector (LOQUET, RICROCH, 2014). This is the case of: the immediate dependency on the work of colleagues (in 2013,43\% of the staff concerned declared such dependency, compared to $30 \%$ for all employees); the obligation of immediately responding to external requests (64\% and 58\% respectively), computerized control or monitoring ( $41 \%$ and $35 \%$ respectively); and even production standards or deadlines to be met within an hour (30\% compared to 27\%). These pace constraints have combined with other forms of time pressure specific to the hospital sector, which have been highlighted by qualitative research: emergency work, work peaks, and work pressure from queuing (GHEORGHIU, MOATTY, 2013). 
This time pressure comes on top of the physical hardships mentioned previously. It can be interpreted as strong work intensity, and may be linked directly to the significant increase in production and productivity observed since the beginning of the 2000s, based on administrative data (OR et al., 2013). This increase in productivity was particularly significant between 2007 and 2008, the year in which T2A was introduced as the sole means of financing hospitals (YILMAZ, FriKhA, 2012). Furthermore, the strong intensity of work has also had an impact on the perception that staff have of their work, on the strategies they develop to make their work bearable, and therefore on their state of health (GolLAC, VolKOFF, 2006). For these reasons, it seems essential to us to better understand this evolution.

\section{A New Analysis of the Evolution of Working Conditions in Hospitals: Factors and Methodology}

We use data from the Working Conditions survey to provide an analysis of the changes in working conditions within the hospital sector, compared to that observed in other sectors. We use the three latest editions of this survey, running from 1998 to 2013. We then focus on the data from the 2013 edition. By controlling for many characteristics, it allows us to compare the current work situation of hospital staff to that of workers from other sectors.

\section{The Monitoring of Work Constraints over Time Based on the Working Conditions Surveys}

We wanted to study the changes in the work constraints faced by workers in the hospital sector, over the recent period. To do this, we chose to use the last three editions of the Working Conditions survey (Box 1), covering the period from 1998 to 2013. We compared these developments with those observed for workers in other sectors.

This survey has two advantages for our analysis. First, it provides detailed information to describe the work constraints faced by employees. Second, as the survey has been carried out regularly since the late 1970s, it makes it possible to understand the evolution of working conditions.

The survey also questioned a large proportion of workers in the hospital sector for each of the editions studied (Table 1). For each edition, we therefore have a sufficient sample to compare the results obtained for hospital staff and for workers in other sectors.

Based exclusively on data from the Working Conditions survey, our analysis is intended to complement the work of J. LOQUET and L. RiCROCH (2014). They studied the evolution of the working conditions of hospital staff between 2003 and 2013, using three different sources: i) the 2003 COTAES survey (Conditions and 
Organization of Work of Employees in Health Establishments); ii) the $2006 \mathrm{COI}-\mathrm{H}$ survey (Organizational Changes and Computerization in the hospital sector); and iii) the 2013 Working Conditions survey (see above). The use of these three surveys met the objective of their study, which was to analyze the evolution of working conditions

\section{Box 1}

\section{Presentation of the Working Conditions Survey}

The Working Conditions survey is a statistical survey which is complementary to the Employment survey (enquête Emploi). It is carried out every seven or eight years mainly by the Ministry of Labour: specifically the Directorate for the Animation of Research, Studies and Statistics (Direction de l'animation de la recherche, des études et des statistiques, DARES), and INSEE (France's National Institute of Statistics and Economic Studies, Institut national des statistiques et des études économiques). The survey provides framework data on the working conditions of France's entire working population in employment. The survey makes it possible to observe as closely as possible real work: i.e. work as perceived by employees; and not prescribed work, described by companies or employers.

The Working Conditions survey was initially conducted in 1978 and the latest edition available (at the time of writing) is for 2013. The survey questionnaire has changed dramatically. Initially it focused on the industrial world, in particular on constraints related to machines. But, the survey has gradually integrated observations on cognitive pressures (responsibilities, attention constraints, etc.), employees' room for maneuver (their power to vary deadlines, etc.), and psychosocial risks. Since 2005, the survey has also been interested in paradoxical injunctions (BUÉ, HAMON-CHOLET, 2006). Finally, the 2013 edition includes a self-questionnaire relating to exposure to psychosocial risks and questions concerning the state of health (the Minimum European Health Module).

TABle 1 - The Main Sets of Questions Relating to Working Conditions: Changes According to Each Survey Edition

\begin{tabular}{|c|c|c|c|c|c|}
\hline Questions related to: & 1984 & 1991 & 1998 & 2005 & 2013 \\
\hline$\ldots$ schedules and the organization of working time & $\mathrm{X}$ & $\mathrm{X}$ & $\mathrm{X}$ & $\mathrm{X}$ & $\mathrm{X}$ \\
\hline$\ldots$ the organization of work & $\mathrm{X}$ & $\mathrm{X}$ & $\mathrm{X}$ & $\mathrm{X}$ & $\mathrm{X}$ \\
\hline ... risk & $\mathrm{X}$ & $\mathrm{X}$ & $\mathrm{X}$ & $\mathrm{X}$ & $\mathrm{X}$ \\
\hline$\ldots$ inconveniences & $\mathrm{X}$ & $\mathrm{X}$ & $\mathrm{X}$ & $\mathrm{X}$ & $\mathrm{X}$ \\
\hline ... work hardships (arduous nature of work) & $\mathrm{X}$ & $\mathrm{X}$ & $\mathrm{X}$ & $\mathrm{X}$ & $\mathrm{X}$ \\
\hline$\ldots$ the content of the work & & $\mathrm{X}$ & $\mathrm{X}$ & $\mathrm{X}$ & $\mathrm{X}$ \\
\hline ... mental pressure/stress/paradoxical injunctions & & $\mathrm{X}$ & $\mathrm{X}$ & $\mathrm{X}$ & $\mathrm{X}$ \\
\hline$\ldots$ the use of machines/new technologies & & $\mathrm{X}$ & $\mathrm{X}$ & $\mathrm{X}$ & $\mathrm{X}$ \\
\hline$\ldots$ accidents at work & & & $\mathrm{X}$ & $\mathrm{X}$ & $\mathrm{X}$ \\
\hline ... occupational health and safety & & & & $\mathrm{X}$ & $\mathrm{X}$ \\
\hline$\ldots$ the state of health & & & & & $\mathrm{X}$ \\
\hline ... psychosocial risks & & & & & $\mathrm{X}$ \\
\hline
\end{tabular}

Interpretation: All the editions (1984 to 2013) include a set of questions on schedules and work organization. Only the 2013 edition includes questions relating to psychosocial risks. 
by professions and types of establishment. ${ }^{5}$ This required large samples for each year studied. ${ }^{6}$ The sources used by the authors allow for more substantial samples than those provided by the Working Conditions survey before 2013: respectively 4,700 workers in the sector in 2003 (COTAES) and 1,400 in 2006 (COI-H). These sample sizes allow for the production of statistics on working conditions, broken down by profession and type of establishment.

In contrast to these authors, therefore, we have chosen to base our analysis on the same source, the Working Conditions survey, for three reasons:

1. Using this source allows us to observe working conditions over a longer period - fifteen years - than that available from the data of the 2003 COTAES and 2006 COI-H surveys. The most important changes within hospital organization took place from the beginning of the 2000s onwards (Box 2). It therefore seems essential to us to have an observation point preceding this date;

2. The survey makes it possible to compare the evolution of working conditions observed within the hospital sector with that of workers in other sectors. In this way, we hope to highlight any specificities of the hospital sector in terms of changing working conditions and analyze them in relationship to the evolution of the sector;

3. Finally, the use of a single source of data to study the way in which the working conditions of workers in the hospital sector have evolved avoids the pitfalls associated with the use of multiple sources. Indeed, as R. LE LAN and D. BAUBEAU (2004), but also J. LOQUET and L. RICROCH (2014) have emphasised, surveys vary in terms of questioning methods, ${ }^{7}$ the order and formulation of the questions, as well as the general or sectoral nature of the survey. These variations may cause exogenous discontinuities in the recording of work constraints faced by employees.

Focusing exclusively on the Working Conditions surveys, however, is not without its own pitfalls. More precisely, it raises two difficulties. The first is linked to the oversampling of the 2013 survey. The numbers surveyed in the last edition are more than four times higher than in the 1998 and 2005 editions (Table 2). Furthermore, the 2013 survey is independent of the INSEE Employment survey, unlike the 1998 and 2005 editions, which were complementary modules to the Employment survey. The sampling base for the over-sampling of workers in the hospital sector was taken from the Information System on Public Service Employees (SIASP, Système d'information sur les agents des services publics) in 2010 for public hospitals, and of the Annual Social Data Declarations (DADS, Déclarations annuelles de données sociales) in 2010 for private hospitals.

5. More precisely, the study "is particularly interested in the differences which could exist within the same professional family, according to the sector of the establishment, i.e. public or private" (LOQUET, RICROCH, 2014, p. 13).

6. Another notable difference is that the constraints of work pace are central in our analysis, while they occupy only a minimal place in the study by J. LOQUET and L. RICROCH (2014).

7. Exclusively face-to-face, at home for the Working Conditions survey; mainly by telephone for the COTAES and COI-H surveys. 
TABLE 2 - Staff Surveyed for Each Edition of the Survey

\begin{tabular}{lrrr}
\hline & $\mathbf{1 9 9 8}$ & $\mathbf{2 0 0 5}$ & $\mathbf{2 0 1 3}$ \\
\hline All sectors & 21,380 & 18,789 & 33,673 \\
Hospital sector & 969 & 910 & 4,327 \\
of which public hospitals & 727 & 521 & 2,760 \\
\hline
\end{tabular}

Interpretation: Of the 33,673 people questioned as part of the Working Conditions survey in 2013, 4,327 worked in the hospital sector, of which 2,760 declared themselves to be employees of a public hospital (the variable "Statut" in the data, referring to different types of job contracts).

Field: Employed workers.

Source: Working Conditions survey, Ministry of Labour, DARES, DGAFP, DREES, INSEE, editions 1998, 2005 and 2013.

\section{Box 2}

\section{The Implementation of the 35-Hour Week in Hospitals}

As in other sectors, the 35-hour week and the cut in working time had adverse effects in hospitals, leading to a deterioration in working conditions. Cuts or even the absence of hiring has favored work intensification. In other words, the volume of hours worked has decreased but work has intensified. Hospitals have evolved like other productive sectors in this respect: the reduction in the working week has resulted in intensified, more flexible and multitasked work (ASKENAZY, 2004). The 35-hour week has thus modified the relationship between working time and life time in particular, by modifying the time availability of the labour force (BOUFFARTIGUE, BOUTEILLER, 2012).

The implementation of T2A has also reinforced the intensification of work. From 2003 to 2009, the growth of activity in public healthcare establishments was faster than the increase in healthcare personnel. The productivity rose in this period by $11.3 \%$, or $1.8 \%$ per year. The increase was even stronger between 2007 and 2008, the year in which T2A became the sole means of financing hospitals (YILMAZ, FRIKHA, 2012). The absolute quest for productivity has shown up in increasing workforce cuts, pressure on healthcare professionals and increased flexibility. This logic has accentuated all kinds of constraints on staff: schedule changes, time overruns, difficulties in choosing vacations freely, tighter management of absences or even recalls when staff are resting (GHEORGHIU, MOATTY, 2013).

A simple comparison between the results of the 2013 survey and those of previous editions could therefore be problematic. However, adjustments made to the 2013 edition of the survey by its producer organizations (DARES, DREES, DGAFP) have made it possible to overcome this difficulty. Several variables in the 2013 sample identify fields that are comparable with previous editions: the main sample indicator makes it possible to identify the workers resulting from the over-sampling (and therefore potentially allows them to be excluded from the analysis); the variable "champ_ct2005" limits the workers present in the 2013 survey to persons covered by the 2005 edition. In addition, several weighting variables were calculated to take these sampling differences into account. For all the changes presented in this article, 
we tested all the tools made available to us. The results for our variables of interest are only very marginally sensitive to field restrictions. To make the results easier to read, we present the evolutions for all the people questioned in 2013, as well as for persons falling within a comparable field to that of 2005 (use of the "champ_ct2005" indicator).

In any case, the field retained, for the three editions studied, concerns employees, including temporary employees, coming from all sectors of activity. Those working in the hospital sector are identified from the code of the Nomenclature of French Activities (the Nomenclature d'activités françaises, or NAF code) for the 1998 and 2005 editions. For the 2013 edition, a combination of the "Statut" variable and the NAF code is used. ${ }^{8}$ This represents 3,944 employees, when including all staff in the sector, and 3,744 individuals if we retain a field comparable to 2005 .

The second difficulty is linked to the general nature of the Working Conditions survey. We want to analyze the differentiated changes in work intensity between the hospital sector and other sectors of activity. In particular, the aim is to check whether the pace of work has accelerated more clearly in hospitals, in connection with the changes experienced by this sector during the period observed. Studying the pace of work within the hospital sector requires having information relating to what directly influences it, such as the flow of patients treated in a day, or the rate of bed turnover. This type of indicator would make it possible to check the way in which workers occupy each unit of time, in order to carry out managers' orders. Thus, as Corinne GAUDART (2015) has emphasized, the intensification of work is measured by the combination of constraints on the pace of work, and the number of operations that must be carried out during time units. By analyzing the evolution of the pace of work using a general survey, we can only apprehend a possible intensification of work through the constraints weighing on such work paces.

To monitor working conditions rigorously during the period of observation, we focused on those which were described continuously between 1998 and 2013 (Box 3). This approach makes it possible to identify the specificities of the hospital sector compared to other sectors of the economy, and also to identify a possible discontinuity in the evolution of exposure to work constraints that are potentially pathogenic for hospital staff.

8. The NAF codes in the 1998 and 2005 editions of the survey are available at a detailed level, which makes it possible to identify hospital establishments directly. By contrast, the 2013 edition only provides a NAF code for 88 positions. As a result, both the employment status and the NAF code must be used to identify all workers in the hospital sector. 


\section{Box 3}

\section{The Work Constraints Studied}

We focus on the four categories of work constraints mentioned above, which are addressed by the same questions in all the editions involved: (1) pace constraints; (2) significant physical exertion; (3) staggered hours and shift work; and (4) an unhealthy working environment.

\section{1 - The pace constraints are identified from answers to the following questions:}

"Your pace of work is imposed by...?

- the automatic movement of a product or part;

- the automatic work rate of a machine;

- other technical constraints;

- immediate dependency on the work of one or several colleagues;

- production standards, or deadlines to be met within one hour at most/one day at most;

- an external request (customers, the public) needing an immediate response/not requiring an immediate response;

- permanent (or at least daily) controls or surveillance carried out by management;

- computerized control or monitoring."

The first five constraints listed here are generally grouped together under the name of "industrial constraints", because they seek to control employees' effort, while the sixth constraint (external demand) is seen as a market constraint, because it follows an external request (GollaC, 2005).

\section{2 - The answers to the following questions are used in order to study exposure to} significant physical exertion:

"Does do your work require you to...?

- remain standing for a long time;

- remain in another uncomfortable or tiring posture for a long time, in the long run;

- move around by foot, for long periods and frequently;

- carry or move heavy loads;

- perform other significant physical efforts;

- be subjected to shocks or vibrations."

3 - Staff affected by staggered working hours are identified using the following series of questions:

"Do you have at least forty-eight consecutive hours of rest per week? (Yes/No).

Do you work nights, between midnight and five o'clock in the morning?

Do you work Saturdays?

Do you work Sundays?

(Usually/Occasionally/Never)"

Persons replying "usually" or "occasionally" to these three questions are considered as affected: i.e. they are exposed to changing working hours. 
4 - The two following questions are used to describe the working environment to which the workers are exposed:

"Do your work and place of work have the following disadvantages:

- dirt;

- humidity;

- drafts;

- infectious risks (microbes, viruses, etc.), parasites;

- lack of or poor sanitary facilities."

"Does your place of work lead you to...?

- inhale fumes;

- inhale dust".

In terms of the working environment, the information gathered from the Working Conditions survey is less precise than that from the SUMER survey, particularly with regard to exposure to chemicals (see above).

\section{The Method Followed to Describe Exposure to Work Constraints Using the 2013 Edition}

After having estimated the evolution of working conditions between 1998 and 2013, we describe more precisely the constraints to which workers in the hospital sector are exposed in 2013. This description is done in two stages.

We first take advantage of the over-sampling of the 2013 survey to put forward an analysis of constraints by profession. Hospital staff are therefore divided into six professional categories, based on the nomenclature of professional families (see the distribution presented in the figure).

The 1998 and 2005 data from the Working Conditions survey are also associated with those collected within the framework of the Employment survey. We therefore have information in areas other than those of working conditions. Although it is independent of the Employment survey, the 2013 Working Conditions edition provides additional information comparable to that available in previous editions. We were thus able to describe the working conditions to which workers in the hospital sector are subjected, all other things being equal. It could indeed be that the differences observed according to the sectors of activity in fact stem from the structure of the professions within the various sectors.

We therefore described the working conditions faced by people in hospitals, using the following equation:

$$
H_{i}=\gamma S_{i}+\beta X_{i}+\varepsilon_{i}
$$

with $i=1, \ldots, N$ and $\varepsilon_{i}$ being the error term.

$H_{i}$ is an indicator variable equal to 1 , if individual $i$ works in a hospital, else 0 . The characteristics of work studied are noted $S_{i}$. 
FIGURE - Distribution by Profession of Workers in the Hospital Sector, in 2013

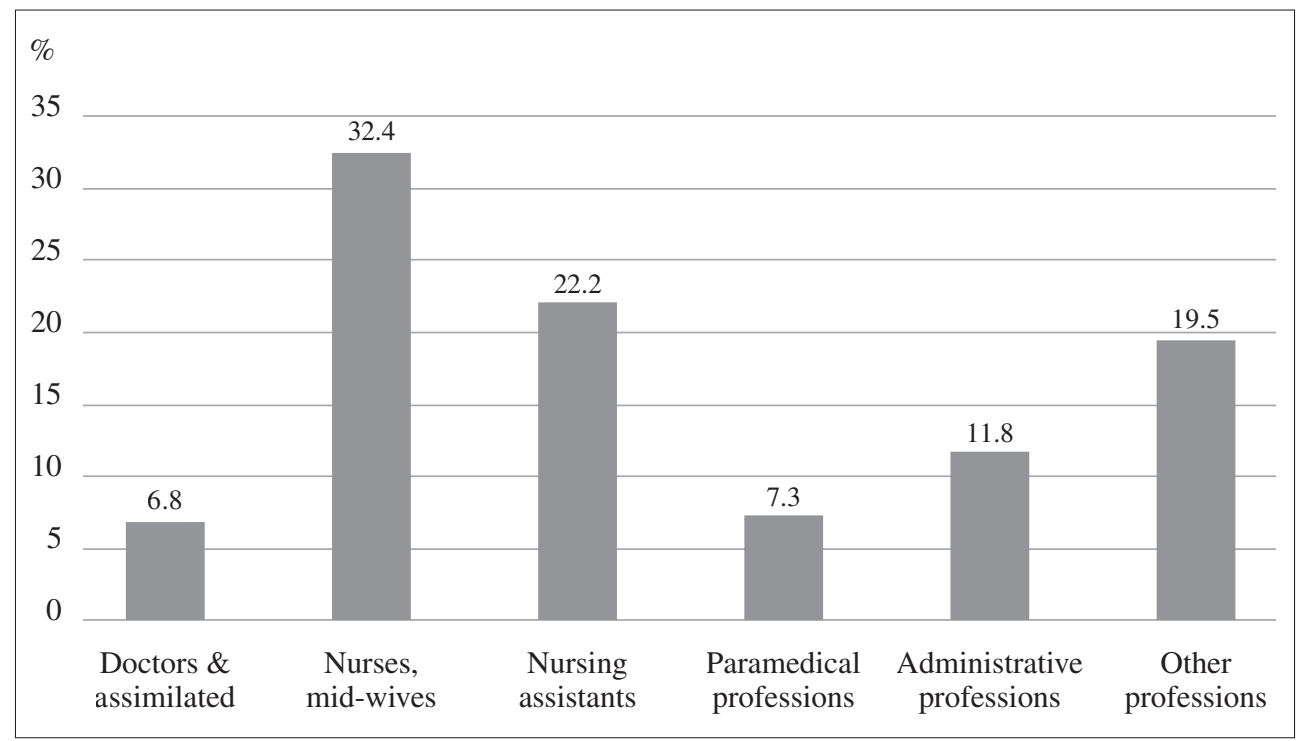

Interpretation: In 2013, 32.4\% of hospital staff were "nurses, mid-wives".

Scope: Employees in the hospital sector.

Source: Working Conditions survey, Ministry of Labour, DARES, DGAFP, DREES, INSEE, 2013 edition.

The control variables that we retained are denoted by $X_{i}$, and can be classified into two groups: the first summarizes the socio-demographic characteristics of the individuals questioned, and integrates age, sex, marital status, educational level, as well as the country of birth; the second includes information on employment conditions, in particular employees' type of contract (permanent or precarious), profession, their sector of activity (public or private), working time (full or part-time), and seniority in the company.

\section{The Over-Exposure to Pace and Hardship Constraints: a Twofold Penalty for Hospital Workers}

\section{Increases in Work Pace Constraints, Decreases in Exposure to Physical Hardship}

Using the last three editions of the Working Conditions survey shows up an increase in exposure to work pace constraints faced by hospital employees (Table 3).

In $1998,79 \%$ of hospital workers were subject to at least one work pace constraint, rising to $82 \%$ in 2005 , and $84 \%$ in 2013 . By contrast, no increase was observed over the same period for workers in other sectors (76\% and 76.8\% in 1998 and 2013 respectively). 
TABLE 3 - Share (in \%) of Employees with Work Pace Imposed by...

\begin{tabular}{|c|c|c|c|c|c|}
\hline & & 1998 & 2005 & 2013 & $\begin{array}{r}2013 \\
-\mathrm{CC}\end{array}$ \\
\hline \multirow{2}{*}{$\begin{array}{l}\ldots \text { the automatic movement of a product } \\
\text { or a component part }\end{array}$} & Hospital sector & 2.1 & 3.2 & 5.9 & 5.6 \\
\hline & Other sectors & 6.5 & 7.2 & 8.3 & 7.5 \\
\hline \multirow{2}{*}{$\ldots$ the automatic rate of a machine } & Hospital sector & 2.4 & 3.0 & 4.2 & 3.9 \\
\hline & Other sectors & 7.7 & 7.3 & 7.3 & 6.9 \\
\hline \multirow{2}{*}{... other technical constraints } & Hospital sector & 13.2 & 15.0 & 19.9 & 19.9 \\
\hline & Other sectors & 15.8 & 15.6 & 16.3 & 16.5 \\
\hline \multirow{2}{*}{$\begin{array}{l}\text {... production standards or deadlines } \\
\text { to be met in one day at most }\end{array}$} & Hospital sector & 36.8 & 40.1 & 47.8 & 48.7 \\
\hline & Other sectors & 42.8 & 41.5 & 41.8 & 43.6 \\
\hline \multirow{2}{*}{ of which in one hour at the most } & Hospital sector & 23.8 & 27.1 & 31.6 & 32.0 \\
\hline & Other sectors & 23.2 & 24.7 & 25.3 & 25.8 \\
\hline \multirow{2}{*}{$\begin{array}{l}\text {... immediate dependence on the work of one } \\
\text { or more colleagues }\end{array}$} & Hospital sector & 37.2 & 36.7 & 43.0 & 43.1 \\
\hline & Other sectors & 26.0 & 25.9 & 27.4 & 28.3 \\
\hline \multirow{2}{*}{... external demand - customers, general public } & Hospital sector & 66.1 & 67.6 & 71.8 & 72.7 \\
\hline & Other sectors & 63.5 & 64.6 & 65 & 68.3 \\
\hline \multirow{2}{*}{ of which requiring an immediate response } & Hospital sector & 61.1 & 61.5 & 64.4 & 65.2 \\
\hline & Other sectors & 53.0 & 53.2 & 54.2 & 56.8 \\
\hline \multirow{2}{*}{$\begin{array}{l}\text {... permanent (or at least daily) controls } \\
\text { or surveillance carried out by the hierarchy }\end{array}$} & Hospital sector & 35.2 & 36.8 & 34.7 & 34.8 \\
\hline & Other sectors & 28.8 & 29.2 & 30.2 & 30.1 \\
\hline \multirow{2}{*}{... computerized control or monitoring } & Hospital sector & nd & 19.7 & 43.2 & 43.5 \\
\hline & Other sectors & nd & 24.9 & 34.2 & 35.3 \\
\hline \multirow{2}{*}{ Workforce } & Hospital sector & 964 & 902 & 3,944 & 3,744 \\
\hline & Other sectors & 17,808 & 16,096 & 26,254 & 22,239 \\
\hline
\end{tabular}

* CC corresponds to individuals from a field comparable with the 2005 edition, i.e. those identified using the "champ_ct2005" variable, provided in the 2013 edition of the survey.

Interpretation: In 2013,47.8\% of workers in the hospital sector were exposed to a work pace constraint linked to compliance with production standards or deadlines to be met in one day at most, compared to $41.8 \%$ of workers in other sectors. The statistics in bold correspond to the work pace constraints for which we observed significant over-exposure (at the $5 \%$ threshold) of workers in the hospital sector, compared to workers in other sectors. Conversely, the statistics in italics correspond to work pace constraints for which we observed a significant over-exposure (statistically speaking) of workers in other sectors, compared to workers in the hospital sector. Field: Active workers in paid employment.

Source: Working Conditions survey, Ministry of Labour, DARES, DGAFP, DREES, INSEE, 1998, 2005 and 2013 editions.

If we look in detail at the different pace constraints faced by employees, we can see an increase in the share of workers having work pace imposed by the automatic movement of products or component parts, or the automatic rate of a machine. This increase is comparable for workers in hospitals and in other sectors.

On the other hand, the increase is much more marked for hospital workers with regard to work rate exposure due to technical constraints, by production standards or deadlines to be respected in a day, and in particular by production standards or deadlines to be met within an hour at most, or by immediate dependence on the work of other colleagues. They are now more frequently subjected to this type of constraint than workers in other sectors. 
Hospital workers are also significantly over-represented ${ }^{9}$ among persons declaring that work pace is imposed by management controls or supervision, whatever the year of observation. This work pace constraint has remained stable over the period, regardless of the sector of activity. ${ }^{10}$

Regarding the pace of work imposed by computerized tracking (observable only for the editions 2005 and 2013), the share of the workers increased significantly between 2005 and 2013 across all sectors. Here again, the increase was significantly greater for hospital staff, who are now significantly over-exposed to this work pace constraint, whereas this was not the case in 2005.

In total, $42 \%$ of hospital staff are exposed to at least one form of industrial work pace constraint (i.e. experiencing a work pace imposed by the automatic movement of a product or a part, by the speed of a machine, by other technical constraints, or even by production standards or deadlines to be respected in one hour at most). This compares to 30\% of staff in such situations at the end of the 1990s and 35\% in 2005 (Table 4). The increase of 12 percentage points between 1998 and 2013 was all the more substantial since no similar increase can be observed in other sectors over the same period (35\% in 1998 and 2005, 37\% in 2013).

This reinforcement of industrial work pace constraints in hospitals has not been accompanied by a relaxation of market constraints (i.e. also experiencing work pace constraints from external demand - customers, the public - requiring immediate responses). On the contrary, in 2013 , more than $65 \%$ of hospital workers declared they were subject to market work pace constraints, compared to $61 \%$ in 1998 and 2005: i.e. there has been an increase of four points in eight years. This again is less noticeable in other sectors of activity.

Differences in exposure have also been very marked in the combination of the two types of constraints, industrial and market/commercial: in 2013,32\% of hospital workers were affected by such combinations, compared to $24 \%$ of workers in other sectors. The increase over the $2005-2013$ period was much greater in hospitals $(+6$ percentage points) than in other sectors of activity ( +2 points).

We must remember at this stage that these work pace constraint indicators reflect only a quantitative part of work pace pressure workers have to face. They are certainly not sufficient to measure the evolution of work intensity during the observation period. That said, the results obtained indicate quite clearly a strengthening of time pressure over fifteen years, especially between 2005 and 2013. And this pressure is exerted more strongly on hospital workers, notably from 2005 onwards, marking a break in the evolution observed here.

\footnotetext{
9. We carried out Chi2 independence tests in order to check whether there is a link between the activity sector (hospital versus other sectors) and all the work pace constraints studied.

10. Even if we observe a slight change in exposure to this constraint, we can consider it to be stable, insofar as the confidence intervals (calculated by the Wald method) over the different periods overlap.
} 
It should be noted that our results contradict those highlighted by the comparison of data from the COTAES 2003, COI-H 2006 and Working Conditions 2013 surveys (LOQUET, Ricroch, 2014). As we stated above, this comparison indicates there was an overall decrease of work pace constraints between 2003 and 2013. By contrast, we observe a significant increase in exposure to all pace constraints in hospitals, especially between 2005 and 2013. These divergent conclusions seem to stem primarily from the COTAES 2003 survey, which appears clearly to overstate exposure to work pace constraints compared to the Working Conditions survey in 2005. For example, having work pace imposed by the immediate dependence on the work of one or more colleagues affected $47 \%$ of hospital workers in 2003 according to the COTAES survey, but only $37 \%$ in 2005 according to the Working Conditions survey. Likewise, $48 \%$ of people questioned as part of the COTAES 2003 survey declared that their pace of work was imposed by production standards or deadlines to be met in one hour, while in the Working Conditions survey it was only $27 \%$. These particularly high exposure levels in 2003 lead J. LOQUET and L. RICROCH (2014) to conclude that work pace constraints had been reduced in the following ten years. We however have noted a worsening of these constraints. In addition to potential differences linked to the differences in sources (see above), the significant difference in exposure to pace constraints between the 2003 and 2005 surveys may be explained by the move to the 35-hour week between 2002 and 2003. This change in the working week initially led to work overload, before necessary recruitments were made, so that caregivers may have experienced a greater sense of urgency in their work.

At the same time, the other forms of constraint fell overall, for all workers during the period of observation (Table 4), with physical constraints including: carrying heavy loads, prolonged standing, long and frequent walking, painful postures, significant physical exertion, jolts or vibrations. The proportion of workers exposed to one of these hardships decreased by 4 points in hospitals and by 3 points in other sectors. Nevertheless, hospital sector personnel remain overexposed to such physical hardships: in $2013,85 \%$ of them declared that they were affected by at least one form of physical constraint at work, compared to just under $70 \%$ among workers in other sectors. Hospital staff are also significantly more likely to occupy positions that combine several physical hardships (55\% and 33\% respectively).

Staggered hours (working weekends, at night, or not having at least forty-eight consecutive hours of rest during a week) also occurred less frequently for all workers in 2013 than in 1998. The drop is particularly noticeable for workers in the hospital sector, where the share of staff on shift work fell from $76 \%$ in 1998 to $71 \%$ in 2013. However, given the obligation of continuity of service, hospital staff all remained more likely to be subject to time constraints and to combine several forms of irregular hours.

Finally, with regard to the risks related to the working environment (dirt, humidity, drafts, infectious risks, parasites, absence or poor condition of sanitary facilities, fumes, dust), hospital workers are more exposed to at least one of these risks (in $2013,89 \%$ versus $64 \%$ in other sectors). They are mainly concerned by the risk of 
TABLE 4 - Share of Employees Stating They Are Exposed to at Least...

\begin{tabular}{|c|c|c|c|c|c|c|c|c|}
\hline & \multicolumn{2}{|c|}{1998} & \multicolumn{2}{|c|}{2005} & \multicolumn{2}{|c|}{2013} & \multicolumn{2}{|c|}{$2013-$ CC $^{*}$} \\
\hline & $\begin{array}{l}\text { Hospital } \\
\text { sector }\end{array}$ & $\begin{array}{l}\text { Other } \\
\text { sectors }\end{array}$ & $\begin{array}{l}\text { Hospital } \\
\text { sector }\end{array}$ & $\begin{array}{l}\text { Other } \\
\text { sectors }\end{array}$ & $\begin{array}{l}\text { Hospital } \\
\text { sector }\end{array}$ & $\begin{array}{l}\text { Other } \\
\text { sectors }\end{array}$ & $\begin{array}{l}\text { Hospital } \\
\text { sector }\end{array}$ & $\begin{array}{l}\text { Other } \\
\text { sectors }\end{array}$ \\
\hline $\begin{array}{l}\ldots \text { an "industrial" } \\
\text { pace constraint }\end{array}$ & 30.1 & 35.2 & 35.0 & 35.1 & 42.2 & 36.8 & 42.3 & 36.8 \\
\hline $\begin{array}{l}\text {.. a "market" } \\
\text { pace constraint» }\end{array}$ & 61.1 & 53.0 & 61.5 & 53.2 & 64.4 & 54.2 & 65.2 & 56.8 \\
\hline $\begin{array}{l}\text {... an industrial } \\
\text { and a market work } \\
\text { pace constraint }\end{array}$ & 22.8 & 20.5 & 25.7 & 21.7 & 32.1 & 23.5 & 32.4 & 23.9 \\
\hline ... a physical constraint & 88.3 & 70.9 & 85.7 & 67.9 & 84.6 & 68.9 & 84.5 & 67.9 \\
\hline $\begin{array}{l}\ldots \text { three physical } \\
\text { constraints } \\
\end{array}$ & 60.1 & 32.7 & 56.0 & 30.9 & 54.6 & 32.5 & 54.6 & 32.4 \\
\hline ... a time constraint & 75.7 & 49.8 & 76.6 & 51.4 & 71.0 & 49.5 & 70.8 & 48.9 \\
\hline ... three time constraints & 46.2 & 16.1 & 45.0 & 14.8 & 41.6 & 15.8 & 41.5 & 16.0 \\
\hline $\begin{array}{l}\ldots \text { an environmental } \\
\text { constraint }\end{array}$ & 88.3 & 54.2 & 87.9 & 58.8 & 89.3 & 63.3 & 89.5 & 63.4 \\
\hline $\begin{array}{l}\text {... three environmental } \\
\text { constraints }\end{array}$ & 14.8 & 17.4 & 21.4 & 25.3 & 23.0 & 27.7 & 22.7 & 27.7 \\
\hline
\end{tabular}

* CC corresponds to individuals from a field comparable with the 2005 edition: i.e. those identified using the "champ_ct2005" variable provided in the 2013 edition of the survey.

Interpretation: In 1998, 88.3\% of workers in the hospital sector declared being exposed to at least one physical constraint, compared to $70.9 \%$ of workers in other sectors.

Field: Active workers in paid employment.

Source: Working Conditions survey, Ministry of Labour, DARES, DGAFP, DREES, INSEE, 1998, 2005 and 2013 editions.

infection. However, unlike in other sectors, exposure to at least one of these risks did not increase between 1998 and 2013. The accumulation of at least three working environment constraints was also less frequent in hospitals, even if it seemed to have increased significantly over the period.

\section{The Specificities of Hospital Staff in Terms of Working Conditions, in 2013}

We have therefore observed a significant increase in work pace constraints, especially for hospital workers, between 1998 and 2013. At the same time, there has been a decrease in exposure to certain physical and time constraints for these same personnel, since the early 2000s.

Nevertheless, hospital staff seem now to face many work constraints. Table 5 shows the intensity of the various constraints to which hospital workers were exposed in 2013, by major occupational group.

Clear disparities in exposure to the various constraints appear between professions. Nurses, midwives and nursing assistants are the most heavily subjected to the constraints studied. Nursing assistants in particular have a very high index of physical hardship, and also face high levels of the other constraints, such as time and environmental constraints. 
TABLE 5 - Exposure of Hospital Staff to the Various Work Constraints, by Profession, in 2013

\begin{tabular}{lcccccc} 
& $\begin{array}{c}\text { Doctors } \\
\text { \& assimilated }\end{array}$ & $\begin{array}{c}\text { Nurses, } \\
\text { mid-wives }\end{array}$ & $\begin{array}{c}\text { Nursing } \\
\text { assistants }\end{array}$ & $\begin{array}{c}\text { Paramedical } \\
\text { professions }\end{array}$ & $\begin{array}{c}\text { Admin } \\
\text { professions }\end{array}$ & $\begin{array}{c}\text { Other } \\
\text { professions }\end{array}$ \\
\hline $\begin{array}{l}\text { Intensity index } \\
\text { a }\end{array}$ & 2.0 & 2.7 & 2.5 & 2.8 & 2.1 & 2.3 \\
\hline $\begin{array}{l}\text { Physical hardship } \\
\text { index }^{\mathrm{b}}\end{array}$ & 1.3 & 2.7 & 3.3 & 2.0 & 0.8 & 2.5 \\
$\begin{array}{l}\text { Hourly constraints } \\
\text { index }^{\mathrm{c}}\end{array}$ & 2.5 & 2.2 & 2.4 & 1.1 & 0.5 & 1.5 \\
$\begin{array}{l}\text { Environmental } \\
\text { nuisance index }\end{array}$ & 1.3 & 1.8 & 2.0 & 1.6 & 1.1 & 2.1 \\
\hline
\end{tabular}

a: average number (between 0 and 8 ) of work pace constraints due to: the automatic movement of a product/component part; to the automatic work rate of a machine; to other technical constraints; to standards of production or deadlines to be respected in one hour at most; to an external request requiring an immediate response; to immediate dependence on the work of colleagues; to controls or surveillance exercised by the management; and to computerized control or follow-up.

b: average number (between 0 and 8 ) of physical constraints, including standing for a long time, being in a painful posture for a long time, making long movements on foot, carrying or moving heavy loads, and being subjected to jolts or vibrations.

c: average number (between 0 and 4) of time constraints, including not having 48 consecutive hours of rest, work on Saturdays, Sundays, or at night work.

$\mathrm{d}$ : average number (between 0 and 7) of environmental constraints, including dirt, humidity, drafts, the risk of infection, poor condition of premises, and fumes or dust.

Interpretation: In 2013, nursing assistants were exposed on average to 2.5 work pace constraints.

Field: Hospital staff in paid employment.

Source: Working conditions survey, Ministry of Labour, DARES, DGAFP, DREES, INSEE, 2013 edition.

Doctors and assimilated professionals have the highest index for time/hourly constraints, but are relatively spared other constraints, particularly physical hardships.

To obtain a more precise inventory of the working conditions for hospital staff, compared to employees in other sectors, we carried out a logit analysis, ceteris paribus. The results of this analysis are detailed in Table 6.

We estimated three different models. The first is denoted M1, and presents a summary "picture" of the constraints to which hospital workers are more or less exposed, by the main sets of constraints (work pace, staggered schedules, physical strain, and an unhealthy working environment). The second model (M2) lists in a systematic and detailed manner all the working conditions that we retained for our comparison of persons questioned, depending on whether they work in hospitals or not. The last model (M3) proposes an analysis of the intensity of work constraints experienced by hospital staff, by estimating the simultaneous exposure to several constraints within each of the four major categories of hardship.

The coefficients estimated from these different models indicate the various work constraints and hardships for which there is a significant difference in exposure between hospital employees and other workers. The positive coefficients indicate an over-exposure of hospital personnel to the corresponding work constraints, ceteris paribus, while the negative coefficients indicate a lower exposure. The parameters associated with work constraints for which there is no significant difference in exposure are noted as "ns" for "not significantly different to".

11. The coefficient estimations of the control variables $\left(X_{i}\right)$ are available on request from the authors. 
TABLE 6 - Description of Working Conditions for Hospital Staff in 2013 (logit models)

\begin{tabular}{|c|c|c|c|}
\hline & M1 & M2 & M3 \\
\hline \multicolumn{4}{|l|}{ Work intensity } \\
\hline \multicolumn{4}{|l|}{ Work pace imposed by... } \\
\hline ... automatic movement of a product or part & & ns & \\
\hline$\ldots$ automatic work rate of a machine & & ns & \\
\hline$\ldots$ other technical constraints & & ns & \\
\hline $\begin{array}{l}\text {... production standards or deadlines to be met in } \\
\text { one hour at most }\end{array}$ & & $0.14^{* * * *}(0.05)$ & \\
\hline $\begin{array}{l}\ldots \text { an external request requiring an immediate } \\
\text { response }\end{array}$ & & ns & \\
\hline $\begin{array}{l}\ldots \text { immediate dependence on the work } \\
\text { of colleagues }\end{array}$ & & $0.39^{* * *}(0.05)$ & \\
\hline $\begin{array}{l}\ldots \text { the controls or surveillance exercised } \\
\text { by management }\end{array}$ & & ns & \\
\hline$\ldots$ computerized control or monitoring & & $0.10^{* * *}(0.05)$ & \\
\hline Be subject to at least one work pace constraint & $0.39^{* * * *}(0.05)$ & & \\
\hline Accumulate at least three work pace constraints & & & ;*** \\
\hline
\end{tabular}

\section{Time/hourly constraints}

\begin{tabular}{|c|c|c|c|}
\hline $\begin{array}{l}\text { Not having } 48 \text { consecutive hours of rest } \\
\text { Working Saturdays } \\
\text { Working Sundays } \\
\text { Working at night }\end{array}$ & & $\begin{array}{c}-0.32^{* * * *}(0.06) \\
-0.16^{* *}(0.07) \\
1.05^{* * *}(0.07) \\
0.43^{* * * *}(0.06)\end{array}$ & \\
\hline Be subject to at least one time/hourly constraint & $0.84^{* * * *}(0.04)$ & & \\
\hline Accumulate at least three time/hourly constraints & & & $1.11^{* * * *}(0.04)$ \\
\hline \multicolumn{4}{|l|}{ Physical constraints } \\
\hline $\begin{array}{l}\text { Standing for a long time } \\
\text { Staying a long time in a painful posture } \\
\text { Moving a lot by foot } \\
\text { Carrying or moving heavy loads } \\
\text { Be subject to jolts or vibrations } \\
\end{array}$ & & $\begin{array}{c}-0.28^{* * *}(0.06) \\
\mathrm{ns} \\
0.79^{* * * *}(0.05) \\
0.63^{* * * *}(0.05) \\
-0.23^{* * * *}(0.07)\end{array}$ & \\
\hline Be subject to at least one physical constraint & $0.53^{* * * *}(0.05)$ & & \\
\hline Accumulate at least three physical constraints & & & $1.21^{* * * *}(0.04)$ \\
\hline \multicolumn{4}{|l|}{ Working environment } \\
\hline $\begin{array}{l}\text { Dirt } \\
\text { Humidity } \\
\text { Drafts } \\
\text { Risks of infection } \\
\text { Poor condition of the premises } \\
\text { Fumes or dust }\end{array}$ & & $\begin{array}{l}\mathrm{ns} \\
-0.66^{* * * *}(0.07) \\
\mathrm{ns} \\
1.88^{* * * *}(0.05) \\
-0.26^{* * * *}(0.07) \\
-0.75^{* * * *}(0.6)\end{array}$ & \\
\hline Be subject to at least one environmental constraint & $1.34^{* * * *}(0.06)$ & & \\
\hline $\begin{array}{l}\text { Accumulate at least three environmental } \\
\text { constraints }\end{array}$ & & & $-0.47^{* * * *}(0.05)$ \\
\hline
\end{tabular}

Note: The specification also includes a set of variables describing the socio-demographic characteristics of individuals and their employment conditions. The estimated parameters associated with these characteristics are available on request from the authors. Interpretation: Significant at thresholds of: ${ }^{* * *} 1 \%,{ }^{* *} 5 \%,{ }^{*} 10 \%$. Standard deviations in parentheses.

Field: Active workers in paid employment.

Source: Working conditions survey, Ministry of Labour, DARES, DGAFP, DREES, INSEE, 2013 edition. 
In terms of exposure to the different forms of constraint/hardship in aggregate (column M1 of Table 6), a systematic over-exposure of hospital staff to all the categories of constraints studied here can be seen. The most significant over-exposure concerns environmental constraints, mainly due to the risk of infection. Next, in order, are the time constraints, the physical hardships and the work pace constraints.

If we break down the various work constraints retained (column M2 of Table 6), the situation of workers in the hospital sector turns out to be more contrasted. They are systematically over-exposed to work pace constraints, and particularly affected by three of the following: i) production standards and deadlines to be met in one hour at most, ii) dependence on the work of colleagues, and iii) computerized monitoring or control.

The reorganizations of work imposed by the reforms since the early 2000 s certainly explain this over-exposure - at least in part. Let us recall here that workers in the hospital sector were initially (in 1998 and 2005 respectively) less exposed than other workers to two of these constraints (standards/deadlines and computerized monitoring: Table 3). These constraints impose a quantity of work to be produced over a period of time. They have certainly led to an increase in work pace rates of personnel in the sector. Yet, the production standards and deadlines to be respected within one day at most, translate the productivity gains and improved quality of care desired by lawmakers. This same tension between quantity and quality is found in the indicators used to assess the performance of emergency services (BELORGEY, 2011). To understand the quality of service, it is customary for a manager to use the waiting time and passage. Reductions in waiting times is understood here by assessors both as an indicator of improved quality of service provided to users, and as an indicator of higher productivity. However, as Nicolas BELORGEY (2011) has emphasized, for staff, this logic is simply equivalent to increasing work rates.

This is made all the more problematic by the emergence of the concept of health democracy, which complicates and lengthens clinical examination - the unique interaction between patient and doctor (BERGERON, 2007). The increasing demands of some patients make the time spent by health care providers more uncertain (SAINSAULIEU, 2006). Change here has been amplified by the greater rotation of patients whose length of stay in hospitals has been shortened (RAVEYRE, UGHETto, 2003). Patients are asking for more information and aspire to being in closer touch with medical teams. But the reinforcement of work pace constraints may lead caregivers to subordinate this expectation of patients so that care providers can improve their performance, which is evaluated in time. Administrative burdens and increasing staff turnover thus limit $d e$ facto the relationship time between patients and staff (HAVARD, NASCHBERGER, 2015).

With regard to time constraints, hospital staff are less concerned by work on Saturdays and by not having at least forty-eight consecutive hours of rest during a week. However, they are significantly more likely to work on Sundays and at night (between midnight and $5 \mathrm{am}$ ). This work pace constraint is not new in hospitals, as it is inherent in the organization of hospitals for the provision of continuity of service. 
But this panorama of time constraints is incomplete. It does not reflect a notable change in the organization of the hospital sector around twelve hours of consecutive work (VINCENT, 2016, 2017). Since 2002, a derogation has allowed caregivers to alternate "long" and "short" working weeks (sixty and twenty-four hours respectively), interspaced by weeks of rest. Such an organization is developing rapidly in the hospital sector, and is being requested by a growing number of employees: many days off, a better work-life balance, but also better patient follow-up linked to longer periods of work and more autonomy in planning tasks, etc. It is also part of a context of stronger performance incentives. However, this new organization of work is quite favorable to healthcare establishments insofar as work in two twelve-hour shifts forces teams to pass on case loads in personal time, so that actual total working time is often longer. Such extended hours of work may, combined with night work, have deleterious effects on health, insofar as it leads to a conflict between work schedules and workers' natural body rhythms (BARTHE, 2015).

Concerning the physical constraints of work, hospital staff are more subject to carrying heavy loads and frequently have to walk long distances in hospitals. These physical constraints affect nursing assistants most, which is coherent with other research results on physical loads carried and musculoskeletal disorders suffered by this category of workers (GADÉA, DIVAY, 2012; LORIOL, 2003). On the other hand, they are less affected than other workers by standing for long periods of time, or being subjected to jolts and vibrations.

Likewise, the environment of hospital workers is characterized by over-exposure to risks of infection. However, these same workers are less often affected by other environmental constraints (dirt, humidity, the poor condition of premises, fumes and dust).

Finally, hospital workers are more numerous, ceteris paribus, in accumulating at least three work constraints simultaneously, for most of the forms of hardship observed (column M3 of Table 6). This is particularly the case for work intensity, staggered hours and physical hardship. By contrast, they are less likely to face at least three environmental constraints.

The study of the last three editions of the Working Conditions survey has enabled us to show statistically the "growing pressure of work pace constraints" (GHEORGHIU, MOATTY, 2013, p. 250) between 1998 and 2013, with a clear acceleration between 2005 and 2013. The latter is clearly greater for workers in the hospital sector, who are now very strongly exposed to work pace constraints linked to compliance with standards or production deadlines, or to dependence of work on one or more colleagues.

These results invite us to look beyond "the overall reduction in work pace constraints" as concluded by J. LOQUET and L. RICROCH (2014, p. 2), and based on a comparison of the Conditions and Organization of Work of Employees in Health 
Establishments (COTAES) survey in 2003, the Organizational Changes and Computerization (COI-H) survey in 2006, and the Working Conditions survey of 2013. Undoubtedly, apart from differences in the sources used, their conclusion was due to an intensity of work which was perceived to be particularly high in 2003, when the shift to the 35-hour week occurred.

The increased time pressure in hospital work has been accompanied by a slight relaxation of "historical" constraints of such work (especially physical and time constraints). Yet, in 2013, workers in this sector remained more often subject to at least one form of staggered schedules, physical hardship and constraints in their working environment. They are also more likely to accumulate simultaneously various forms of work pace constraints, staggered schedules and physical hardship.

\section{REFERENCES:}

ACKER, F. (2005). « Les reconfigurations du travail infirmier à l'hôpital. » Revue française des affaires sociales, (59)1, 161-181.

Algava, É., Davie, E., Loquet J., and Vinck L. (2014). «Conditions de travail: reprise de l'intensification du travail chez les salariés. » Dares analyses, no 049.

Amossé, T., GollaC, M. (2008). «Intensité du travail et mobilité professionnelle. » Travail et Emploi, 113, 59-73.

Arnaudo, B., Léonard, M., SAndret, N., Cavet, M., Coutrot, T., Rivalin, R., and Thierus L. (2013). «Les risques professionnels en 2010: de fortes différences d'exposition selon les secteurs. » Dares analyses, no 010.

Askenazy, P. (2004). Les Désordres du travail. Paris: Éditions du Seuil.

BARTHE, B. (2015). «La déstabilisation des horaires de travail. » In A. Thébaud-Mony, P. Davezies, L. Vogel, and Volkoff S. (Eds.), Les Risques du travail (pp. 223-232). Paris: La Découverte.

BeLorgey, N. (2010). L'Hôpital sous pression. Enquête sur le nouveau management public. Paris: La Découverte.

BELORGEY, N. (2011). « Réduire le temps d'attente et de passage aux urgences. Une entreprise de "réforme" d'un service public et ses effets sociaux. » Actes de la recherche en sciences sociales, 189, 16-33.

BERGERON, H. (2007). « Les transformations du colloque singulier médecin/patient: quelques perspectives sociologiques. » In D. Tabuteau (Ed.), Les Droits des malades et des usagers $d u$ système de santé, une législature plus tard (pp. 35-47). Paris: Presses de Sciences Po.

Bouffartigue, P., Bouteiller, J. (2012). Temps de travail et temps de vie. Les nouveaux visages de la disponibilité temporelle. Paris: Presses universitaires de France.

Bué, J., Coutrot, T., Hamon-Cholet, S., and Vinck, L. (2007). « Conditions de travail : une pause dans l'intensification. » Premières synthèses, no 01.2. 
Bué, J., Hamon-Cholet, S. (2006), «Présentation des enquêtes sur les conditions de travail menées en France depuis 1978. » Santé, société et solidarité, 2, 139-142.

CORDiER, M. (2009). «L'organisation du travail à l'hôpital : évolutions récentes. » Études et résultats, no 709.

Couty, É. (2013). Le Pacte de confiance pour l'hôpital. Paris: Ministère de la Santé.

Divay, S., GAdÉA, C. (2008). «Les cadres de santé face à la logique managériale. » Revue française d'administration publique, 128, 677-687.

Domin, J.-P. (2015). « Réformer l'hôpital comme une entreprise. Les errements de trente ans de politique hospitalière (1983-2013). » Revue de la régulation, 17.

ESTRYN-BÉHAR, M. (2008). Santé et satisfaction des soignants au travail en France et en Europe. Rennes: Presses de l'EHESP.

GadÉA, C., DivaY, S. (2012). «Les professionnels du soin en proie aux troubles musculosquelettiques. » In C. Courtet, M. Gollac (Eds.), Risques du travail, la santé négociée (pp. 249263). Paris: La Découverte.

GAUdART, C. (2015). «Intensification du travail: le temps soustrait. » In A. Thébaud-Mony, P. Davezies, L. Vogel, and S. Volkoff (Eds.), Les Risques du travail: pour ne pas perdre sa vie à la gagner (pp. 196-206). Paris: La Découverte.

Gheorghiu, M. D., Montty, F. (2005). Les conditions de travail en équipe. Document de travail du Centre d'études de l'emploi, no 43.

Gheorghiu, M. D., MoATty, F. (2013). L'Hôpital en mouvement. Changements organisationnels et conditions de travail. Paris: Éditions Liaisons.

Gollac, M. (2005). «L'intensité du travail. » Revue économique, (56)2, 195-216.

Gollac, M., Volkoff, S. (2006). « La santé au travail et ses masques. » Actes de la recherche en sciences sociales, 163, 4-17.

Havard, C., Naschberger, C. (2015). «L'influence du patient sur le travail des soignants et le dialogue social à l'hôpital. » @ GRH, 17, 9-41.

Kranklader, É., Minodier, C., Fourcade, N. (2013). «Établissements de santé : le personnel soignant de plus en plus âgé. » Études et résultats, no 846.

Lamy, S., Gaudemaris, R. (DE), Sobaszek, A., Caroly, S., Descatha, A., \& Lang, T. (2013). «Améliorer les conditions de travail à l'hôpital: ORSOSA, de la démarche de recherche à l'action de prévention. » Santé publique, 25(4), 389-397.

LASFARgues, G. (2005). Départs en retraite et travaux pénibles, l'usage des connaissances scientifiques sur le travail et ses risques à long terme pour la santé. Paris: Centre d'études de l'emploi.

LE LAN, R., BAUBEAU, D. (2004). « Les conditions de travail perçues par les professionnels des établissements de santé. » Études et résultats, no 335. 
Loquet, J., Ricroch, L. (2014). « Les conditions de travail dans les établissements de santé. » In B. Boisguerin, G. Brilhault (Eds.), Le Panorama des établissements de santé - 2014 (pp. 9-30). Paris: Drees.

LORIOL, M. (2003). « La construction sociale de la fatigue au travail: l'exemple du burn out des infirmières. » Travail et Emploi, 94, 65-74.

Molinié, A.-F., VolkofF, S. (2006). « Fins de vie active et pénibilités du travail. » In Y. L'HorTy (Ed.), La Qualité de l'Emploi (pp. 95-104). Paris: La Découverte.

Newhouse, J. P. (2003). “Reimbursing for Health Care Service.” Économie publique, 13, 3-31.

Noguera, F., LARTigaU, J. (2009). « De la prospective à la gestion prévisionnelle des métiers et des compétences dans la fonction publique hospitalière : enjeux et perspectives. » Management et avenir, 25, 290-314.

Or, Z., Bonastre, J., Journeau, F., Nestrigue, C. (2013). Activité, productivité et qualité des soins des hôpitaux avant et après la T2A. Document de travail no 56, Paris: IRDES.

Pierru, F. (2007). Hippocrate malade de ses réformes. Bellecombe-en-Bauges: Éditions du Croquant.

Raveyre, M., Ughetto, P. (2003). « Le travail, part oubliée des restructurations hospitalières. » Revue française des affaires sociales, (57)3, 95-119.

SAINSAUlieU, I. (2006). «Les appartenances collectives à l'hôpital. » Sociologie du travail, (48) $1,72-87$.

SCANLON, W. J. (2006). "The Future of Medical Hospital Payment. Modest Proposal in Light of Medicare's Challenge." Health Affairs, (25)1, 70-80.

Silverman, E., Skinner, J. (2004). "Medicare Upcoding and Hospitals Ownership.” Journal of Health economics, (23)2, 369-389.

VALEyre, A. (2001). « Le travail industriel sous la pression du temps. » Travail et Emploi, 86, 127-149.

VINCENT, F. (2017). «Penser sa santé en travaillant en 12 heures. Les soignants de l'hôpital public entre acceptation et refus. » Perspectives interdisciplinaires sur le travail et la santé (Pistes), (19)1, 1-19.

VinCENT, F. (2016). Un temps qui compte. Une sociologie ethnographique du travail « en 12 heures » à l'hôpital public. (Thèse de sociologie, Paris, Université Paris Dauphine).

Yilmaz, E., FrikHA, S. (2012). «Les hôpitaux publics ont amélioré leur efficience entre 2003 et 2009. » In B. Boisguerin, C. Minodier (Eds.), Le Panorama des établissements de santé (pp. 51-65). Paris: Drees. 
